Ivan the Terrible 



\title{
Ivan the Terrible
}

First Tsar of Russia

\author{
Isabel de Madariaga
}

Yale University Press

New Haven and London 
Copyright $@ 2005$ by Isabel de Madariaga

All rights reserved. This book may not be reproduced in whole or in part, in any form (beyond that copying permitted by Sections 107 and 108 of the U.S. Copyright Law and except by reviewers for the public press), without written permission from the publishers.

For information about this and other Yale University Press publications, please contact:

U.S. Office: sales.press@yale.edu yalebooks.com Europe Office: sales@yaleup.co.uk www.yalebooks.co.uk

Set in Sabon by MATS, Southend-on-Sea, Essex Printed in Great Britain by St Edmundsbury Press Ltd, Bury St Edmunds

Library of Congress Cataloging-in-Publication Data

De Madariaga, Isabel, 1919-

Ivan the Terrible/Isabel de Madariaga._- 1st ed.

p. $\mathrm{cm}$.

Includes bibliographical references and index.

ISBN 0-300-09757-3 (cl.: alk. paper)

1. Ivan IV, Tsar of Russia, 1530-1584.2. Russia-Tsars and rulers-Bibliography. 3. Russia-History-Ivan IV, 1533-1584.

I. Title.

DK106.D4 2005

947'.043'092—dc22

2004029807

A catalogue record for this book is available from the British Library. 